\title{
The Impact of Human Activities on Biological Evolution: A Topic of Consideration for Evolution Educators
}

\author{
Ron Wagler
}

Published online: 24 March 2011

(C) Springer Science+Business Media, LLC 2011

\begin{abstract}
There is a definitive need, at all science education levels, to strongly emphasize the central anthropogenic role humans now play in current evolutionary processes and biosphere impact. This article presents a brief overview of recent human activities; broad examples of the impact of human activities on biological evolution; a general overview and specific examples of incorporating human activities into evolution education; and further online anthropogenic resources that can be incorporated into educational settings.
\end{abstract}

Keywords Anthropogenic · Biosphere - Education .

Educators $\cdot$ Environmental $\cdot$ Evolution $\cdot$ Extinction .

Human $\cdot$ Pedagogy $\cdot$ Science

\section{Introduction}

As humans (Homo sapiens; see Fig. 1), we often find it difficult to think of ourselves as animals that interact with the environment. Frans B. M. de Waal has named this condition "anthropodenial: a blindness to the humanlike characteristics of other animals, or the animal-like characteristics of ourselves" (de Waal 1997, p. 50). When a North American beaver (Castor canadensis; see Fig. 1) builds a dam, we somehow perceive it differently than when we build a dam. But from an evolutionary perspective, we are both mammal species doing what we do because of our past

\footnotetext{
R. Wagler $(\square)$

Department of Teacher Education,

The University of Texas at El Paso,

500 West University Avenue, Education Building 601,

El Paso, TX 79968-0574, USA

e-mail: rrwagler2@utep.edu
}

evolutionary histories - evolutionary histories that at one time in the not so distant geological past, were shared. We both perform environmentally modifying activities (e.g., dam building) throughout our lives that are consistent with our shared and divergent evolutionary characteristics. While over the last 250 to 300 years the North American beaver's collective activities and number have declined because of humans, the collective activities and number of humans over this same time period have drastically increased.

\section{A Brief Overview of Recent Human Activities}

The number of humans on Earth at any one time has grown astronomically over the last two 250 to 300 years. Two thousand years ago, there were 300 million humans on Earth. One thousand years ago, there were 310 million humans on Earth, and 260 years ago, there were 790 million humans on Earth (all values are approximate; United Nations 1999). In the last 260 years, the human population has increased by 6.1 billion people. Currently, there are 6.9 billion humans on Earth, and the human population is projected to be 9.3 billion by 2050 (all values are approximate; U.S. Census Bureau 2010).

Humans have become the greatest geophysical force on Earth (Lewis 2006; Steffen et al. 2007; Wilkinson 2005). We currently use more than half of all accessible fresh water (Crutzen 2002) and between a third and half of all land on Earth (Lewis 2006). We have built reservoirs that hold from three to six times as much water as in natural rivers, and we now move more soil, rock, and sediment than all natural processes combined (Lewis 2006). We use more nitrogen fertilizer than is fixed in all natural terrestrial ecosystems and produce 


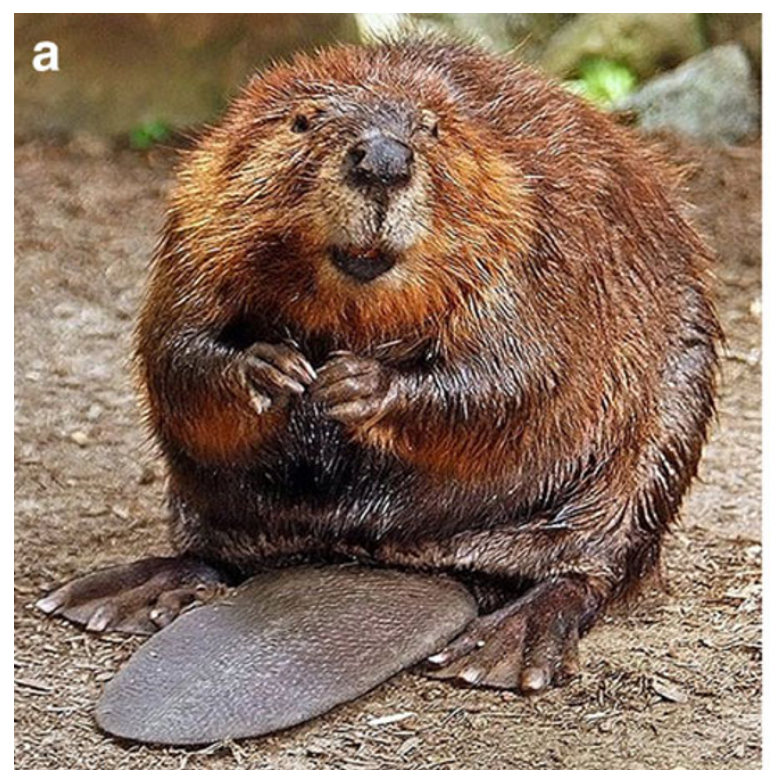

Fig. 1 a) North American Beaver (C. canadensis) (this file is licensed under the Attribution-Share Alike 2.0 Generic license. Source: http://upload.wikimedia.org/wikipedia/commons/6/6b/ American_Beaver.jpg). b) Male and female human (H. sapiens)

more nitric oxide than all natural sources combined (Crutzen 2002).

During the last century, human energy use has grown sixteenfold, "causing 160 million tonnes of atmospheric sulphur dioxide emissions per year, more than twice the sum of its natural emissions" (Crutzen 2002, p. 23). Global fossil fuel emissions increased 41\% from 1990 to 2008 and 29\% from 2000 to 2008 (Le Quéré et al. 2009), increasing atmospheric $\mathrm{CO}_{2}$ to its highest levels in 15 million years and driving global warming, rising sea levels, and climate change (Tripati et al. 2009). Through construction and agriculture, humans have caused a dramatic increase in global erosion and the denudation of continents. This increase in erosion now exceeds natural sediment production by an order of magnitude (Syvitski et al. 2005; Wilkinson 2005). Based on global human consumption rates, the global human ecological footprint exceeded Earth's biocapacity in the mid to late 1980s (WWF 2008) and "now exceeds the planet's regenerative capacity by about 30 percent. This global overshoot is growing and, as a consequence, ecosystems are being run down and waste is accumulating in the air, land and water" (WWF 2008, p. 2).

\section{Broad Examples of the Impact of Human Activities on Biological Evolution}

On a smaller scale, human activities influence the evolution of organisms such as agricultural pests, agricultural weeds,

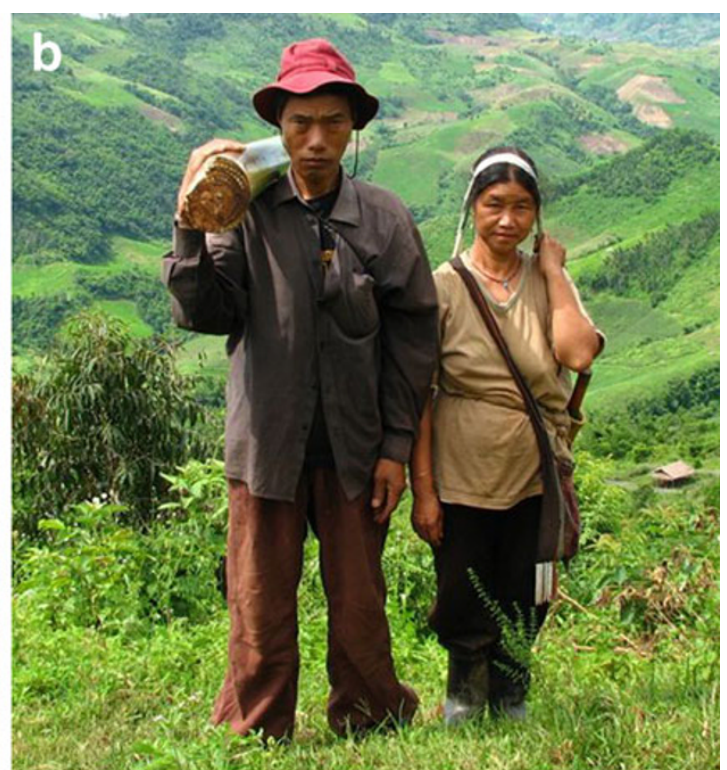

(this file is licensed under the Creative Commons Attribution-Share Alike 2.0 Germany license. Source: http://upload.wikimedia.org/ wikipedia/commons/d/dc/Akha_couple.JPG)

and bacteria. Humans continually develop and apply new pesticides to control agricultural pests and new herbicides to control agricultural weeds. In 2000, humans used 700 million pounds of pesticide in the United States alone (NRC 2000). Typically, within ten years after the introduction of a newly developed pesticide, insects evolve resistance to this new compound (NRC 2000). In some cases, agricultural pest species have evolved resistance to so many pesticides that control is futile (NRC 1986).

Analogous evolutionary outcomes are observed in agricultural weeds that often evolve resistance within ten to 25 years of the application of a newly developed herbicide (Heap 1997). Similar trends of human-induced evolution are also observed in bacteria when inefficient use of antibiotics drives evolution, making human diseasecausing bacteria resistant to many antibiotics. Some of these inefficient uses driving bacterial evolution include overprescribing antibiotics (Nyquist et al. 1998) and not completing a course of antibiotics (Wong et al. 1997; Lazarus and Sanders 2000). Further human-induced evolution of bacteria occurs in livestock production where evolved resistance is also observed (Levy 1994).

Beyond what is observed in agricultural pests, agricultural weeds, and bacteria, far more profound large-scale human-induced evolutionary consequences are under way, with $65 \%$ of global aquatic river habitat under moderate to high threat (Vörösmarty et al. 2010). Approximately two thirds of all organisms occur in the tropics, mainly in tropical humid forests, and more than half of the tropical humid forests on Earth have been destroyed. At the current 
rate of destruction, it is estimated that the remaining tropical humid forests and the organisms they contain will be destroyed by 2060 (Pimm and Raven 2000), putting an end to these species' long evolutionary histories.

Based on anthropogenic activity over the past 250 to 300 years, humans have accelerated global species extinction rates 100 to 1,000 times that of Earth's historical geological background rate (Mace et al. 2005; Pimm et al. 1995; Rockström et al. 2009), ushering in the sixth great mass extinction in evolutionary history (Alroy 2008; Crutzen and Stoermer 2000; IUCN 2010; Jackson 2008; Lewis 2006; McDaniel and Borton 2002; Rockström et al. 2009; Rohr et al. 2008; Steffen et al. 2004; Steffen et al. 2007; Thomas et al. 2004; Wake and Vredenburg 2008; Zalasiewicz et al. 2010). Future extinction rates, based on computer modeling, are projected to be 10,000 times Earth's historical geological background rate (MEA 2005). Considering these everincreasing anthropogenic activities as a whole, there is a high probability that complex major evolutionary radiations have been and will be lost in the near future (MEA 2005a).

As with the current great mass extinction, the evolution of life on Earth has been greatly influenced by past mass extinctions. After all five past great mass extinctions (i.e., Ordovician-Silurian Extinction (circa 439 MYA); Late Devonian Extinction (circa 364 MYA); Permian-Triassic Extinction (circa $251 \mathrm{MYA}$ ); End Triassic Extinction (circa 199-214 MYA); Cretaceous-Tertiary Extinction (circa 65 MYA); (Erwin 2001; Jablonski 1995), very slow recovery was facilitated by the evolution of new species instead of the re-expansion of the survivors (Veron 2008). If the last five great mass extinctions are any indication of what will occur after the current human-induced mass extinction, it can be expected that "evolutionary processes would not generate a replacement stock of species within less than several million years" (Myers et al. 2000).

\section{A General Overview and Specific Examples of Incorporating Human Activities into Evolution Education}

The degree to which humanity, as a species, has impacted biological evolution and the biosphere has been made evident by science. Yet this science is surprisingly missing from most science curricula, state science educational standards, and national science educational standards at almost any educational level except for scant examples of evolutionary change in bacteria (e.g., inefficient use of antibiotics) and RNA viruses (e.g., the need for new seasonal influenza vaccine every year). There is a definitive need at all science educational levels to strongly emphasize the central anthropogenic role humans now play in current evolutionary processes and biosphere impact.
One of the ways to highlight this content is by incorporating free online anthropogenic research and anthropogenic research reports, such as the World Wide Fund for Nature (WWF) and the Millennium Ecosystem Assessment (MEA), into current science classroom curriculum. For example, science educators can begin to address and emphasize many specific anthropogenic evolution questions with their students by using five of the most ecologically devastating and far-reaching anthropogenic direct drivers that currently affect global biodiversity and species evolution: (1) habitat modification, fragmentation, and destruction; (2) overexploitation of species; (3) the spread of invasive species and genes; (4) pollution; and (5) climate change (MEA 2005; MEA 2005a; WWF 2008; WWF 2010).

Examples of activity-driven questions from WWF (WWF 2008; WWF 2010) and MEA (MEA 2005; MEA 2005a) reports may include but are not limited to: When humans modify, fragment, or destroy habitats, how does this affect gene flow and genetic drift of a species? What is the relationship between human overexploitation of a species, its evolutionary fitness, and its gene pool variability? What does human-induced extinction do to a species' evolutionary history? How does anthropogenic pollution impact biological evolution? What role do human-induced invasive genes play within evolution? How do humaninduced invasive species impact coevolution? Further free online anthropogenic resources are listed in the bibliography. These resources have the potential for the development of many question-driven activities that address the current impact human activities are having on biological evolution.

Inquiry-learning pedagogy (e.g., scientific inquiry [NRC 1996]; problem-based learning; 5E learning cycle, and instructional model [Bybee 1997]) that is integrated with technology (e.g., TOXMAP and Google Earth) should be used to allow students to fully investigate these evolution questions and also to fully understand the complexity of the environmental issues and problems humanity currently faces and will face in the next 50 to 100 years. When possible, field trips should also be taken to local sites that have been impacted by human activities. Students can collect data assessing the level of anthropogenic change and discuss the impact that these human activities may have or have had on local species evolution and the ecosystem in general. Anthropogenic field trips bring a sense of authenticity to the educational experience by allowing students to experience first-hand the environmental degradation occurring where they live. These experiences can then be brought back to the classroom for further in-depth discussion.

Beyond a focus on integrated science content (i.e., humanity's impact on biological evolution and the biosphere), inquiry-learning pedagogy integrated with technology, and the use of local anthropogenic field trips, question-driven 
activities should place special emphasis on how humanity can begin to decelerate the anthropogenic trajectory we are currently on. This issue can be investigated by exploring the two main overarching factors driving present global environmental degradation: the size and the natural resource consumption rate of the human population. These questiondriven activities should also be framed by the understanding that as a general trend, the highest per capita human natural resource consumption rate is occurring in the more developed countries and that the greatest human population growth is occurring in the less developed countries. Emphasis should also be placed on examples of the development and implementation of more efficient and more environmentally sustainable human activities coupled with an awareness that an individual in a more developed country such as the United States consumes much more natural resources per capita than an individual in a less developed country. Therefore, directly or indirectly, an individual in a more developed country causes much more environmental degradation than an individual in a less developed country. Lastly, special emphasis should also be placed on how humanity, the collective students of the class, the teacher, and the individual student can ethically and equitably begin to reduce both of these overarching factors by changing current behaviors.

\section{Conclusion}

Clearly, the past, present, and future activities of humans have and will increasingly change and end by extinction the evolutionary history of many species. The degree to which these future evolutionary changes and extinctions will occur is uncertain. Education may be a mechanism that can play a role in beginning to slow the anthropogenic activities that are directly and indirectly impacting global organismal evolution. To this end, there is a need for those in evolution education, environmental education, and science education in general to develop curricula that address and strongly emphasize the everincreasing impact humans are having on the evolution of other organisms and on the biosphere.

\section{References}

Alroy J. Dynamics of origination and extinction in the marine fossil record. Proceedings of the National Academy of Sciences. 2008; 105:1 11536-11542 Available at http://www. pnas.org/content/105/suppl.1/11536.full (the document is available free online).

Bybee RW. Achieving scientific literacy. Portsmouth: Heinemann; 1997. Crutzen PJ. Geology of man. Nature. 2002;415:23.
Crutzen PJ, Stoermer EF. The Anthropocene. Global Change Newsletter. 2000; 41 17-18 Retrieved November 24, 2010 from http://www.igbp.net/documents/resources/NL_41.pdf (the document is available free online).

de Waal FBM. Are we in Anthropodenial? Discover. 1997; 18:7 50-53 Available at http://www.emory.edu/LIVING_LINKS/ OurInnerApe/pdfs/anthropodenial.html (the document is available free online).

Erwin DH. Lessons from the past: biotic recoveries from mass extinctions. Proceedings of the National Academy of Sciences. 2001; 98 1399-1403 Available at http://www.pnas.org/content/ 98/10/5399.full (the document is available free online).

Heap IM. The occurrence of herbicide-resistant weeds worldwide. Pestic Sci. 1997;51:235-43.

International Union for Conservation of Nature Red List (IUCN). Red list of threatened species. The IUCN Species Survival Commission. 2010. Retrieved November 16, 2010 from http://www. iucnredlist.org (the document is available free online).

Jablonski D. In RM May \& JH Lawton, editors. Extinction rates. Oxford University Press: Oxford; 1995. p. 25-44.

Jackson JBC. Ecological extinction and evolution in the brave new ocean. Proceedings of the National Academy of Sciences. 2008; 105 11458-11465 Available at http://www.pnas.org/content/ early/2008/08/08/0802812105.abstract (the document is available free online).

Lazarus A, Sanders J. Management of tuberculosis: choosing an effective regimen and ensuring compliance. Postgrad Med. 2000;108(2):71-84.

Le Quéré C, Raupach MR, Canadell JG, Marland G, et al. Trends in the sources and sinks of carbon dioxide. Nat Geosci. 2009;2:831-6.

Levy S. The antibiotic paradox: how miracle drugs are destroying the miracle. New York: Plenum Press; 1994.

Lewis SL. Tropical forests and the changing earth system. Philos Trans R Soc B. 2006;361:195-210.

Mace G, Masundire H, Baillie $J$ et al. Biodiversity in ecosystems and human well-being: current state and trends. Hassan, H., Scholes, R. \& Ash, N., (Eds.). Island Press: Washington DC. 2005; $77-$ 122 Retrieved November 24, 2010 from http://www.maweb.org/ en/index.aspx (the document is available free online).

McDaniel CN, Borton DN. Increased human energy use causes biological diversity loss and undermines prospects for sustainability. Bioscience. 2002;52(10):926-36.

Millennium Ecosystem Assessment (MEA). Millennium ecosystem assessment: ecosystems and human well-being (synthesis report). 2005. Retrieved November 24, 2010 from http://www.maweb. org/en/index.aspx (the document is available free online).

Millennium Ecosystem Assessment (MEA). Millennium ecosystem assessment: ecosystems and human well-being (biodiversity synthesis report). 2005a. Retrieved November 24, 2010 from http://www. maweb.org/en/index.aspx (the document is available free online).

Myers N, Mittermeier RA, Mittermeier CG, da Fonseca GAB, Kent J. Biodiversity hotspots for conservation priorities. Nature. 2000;403:853-8.

National Research Council (NRC). Pesticide resistance: strategies and tactics for management. National Academy Press: Washington, DC. 1986. Available at http://www.nap.edu/openbook.php? record $\mathrm{id}=619$ (the document is available free online).

National Research Council (NRC). National Science Education Standards. National Academy Press: Washington, DC. 1996. Available at http://www.nap.edu/catalog.php?record_id $=4962$ (the document is available free online).

National Research Council (NRC). The future role of pesticides in US agriculture. National Academy Press: Washington, DC. 2000. Available at http://www.nap.edu/catalog.php?record_id $=9598$ (the document is available free online). 
Nyquist AC, Gonzales R, Steiner JF, Sande MA. Antibiotic prescribing for children with colds, upper respiratory tract infections, and bronchitis. Journal of the American Medical Association. 1998; 279:11 875-877 Available at http://jama.ama-assn.org/cgi/reprint/ $279 / 11 / 875$ (the document is available free online).

Pimm SL, Raven P. Extinction by numbers. Nature. 2000;403:843-5. doi: $10.1038 / 35002708$.

Pimm SL, Russell GJ, Gittleman JL, Brooks TM. The future of biodiversity. Science. 1995;269:347-50.

Rockström J, Steffen W, Noone K, Persson Å, Chapin FS, Lambin EF, et al. A safe operating space for humanity. Nature. 2009;461:472-5. doi:10.1038/461472a.

Rohr JR, Raffel TR, Romansic JM, McCallum H, Hudson PJ. Evaluating the links between climate, disease spread, and amphibian declines. Proceedings of the National Academy of Sciences. 2008; 105: 45 11536-11542 Available at http://www. pnas.org/content/105/45/17436.full (the document is available free online).

Steffen W, Sanderson A, Tyson PD, Jaeger J, Matson PA, Moore, B, III Oldfield F, Richardson K, Schnellnhuber HJ, Turner BL, Wasson RJ. Global change and the earth system: a planet under pressure. Springer-Verlag: Berlin. 2004. (See also the executive summary at http://www.igbp.net/documents/IGBP_ExecSummary.pdf) (the document is available free online).

Steffen W, Crutzen PJ, McNeill JR. The Anthropocene: are humans now overwhelming the great forces of nature? Ambio. 2007;36:614-21.

Syvitski JPM, Vörösmarty CJ, Kettner AJ, Green P. Impact of humans on the flux of terrestrial sediment to the global coastal ocean. Science. 2005;308:376-80. doi:10.1126/science.1109454.

Thomas CD, Cameron A, Green RE, Bakkenes M, Beaumont LJ, Collingham $\mathrm{YC}$, et al. Extinction risk from climate change. Nature. 2004;427:145-8.

Tripati AK, Roberts CD, Eagle RA. Coupling of $\mathrm{CO}_{2}$ and ice sheet stability over major climate transitions of the last 20 million years. Science. 2009;326:1394-7. doi:10.1126/science.1178296.
United Nations. The world at six billion. 1999. Retrieved November 11, 2010 from http://www.un.org/esa/population/publications/ sixbillion/sixbilpart1.pdf (the document is available free online).

USA Census Bureau. Total midyear population for the world. 2010; 1950-2050. Retrieved November 11, 2010 from http://www.census. gov/ipc/www/idb/worldpop.php (the document is available free online).

Veron JEN. Mass extinctions and ocean acidification: biological constraints on geological dilemmas. Coral Reefs. 2008;27:45972. doi:10.1007/s00338-008-0381-8.

Vörösmarty $\mathrm{CJ}$ et al. Global threats to human water security and river biodiversity. Nature. 2010;467:555-61. doi:10.1038/nature09440.

Wake DB, Vredenburg VT. Are we in the midst of the sixth mass extinction? A view from the world of amphibians. Proceedings of the National Academy of Sciences. 2008; 105 11466-11473 Available at http://www.pnas.org/content/early/2008/08/08/ 0801921105.abstract (the document is available free online).

Wilkinson BH. Humans as geologic agents: a deep-time perspective. Geology. 2005;33(3):161-4. doi:10.1130/G21108.1.

Wong JK et al. Reduction of HIV-1 in blood and lymph nodes following potent antiretroviral therapy and the virologic correlates of treatment failure. Proceedings of the National Academy of Science of the United States of America. 1997; 94:23 12574 12579 Available at http://www.pnas.org/content/94/23/12574. full.pdf $+\mathrm{html}$ (the document is available free online).

World Wide Fund for Nature (WWF). Living planet report 2008. 2008. Retrieved November 30, 2010 from http://assets.panda.org/ downloads/living planet report 2008.pdf (the document is available free online).

World Wide Fund for Nature (WWF). Living planet report 2010. 2010. Retrieved November 15, 2010 from http://wwf.panda.org/ about_our_earth/all_publications/living_planet_report/2010_lpr/ (the document is available free online).

Zalasiewicz J, Williams M, Steffen W, Crutzen P. The new world of the Anthropocene. Environ Sci Technol. 2010;44(7):2228-31. doi:10.1021/es903118j. 